\title{
TETRAZOLIUM TEST TO ESTIMATE OKRA (Abelmoschus esculentus (L.) MOENCH) SEED VIABILITY ${ }^{1}$
}

\author{
ANTÔNIA ADAILHA TORRES SOUZA ${ }^{2}$, NARJARA WALESSA NOGUEIRA ${ }^{2}$, SALVADOR BARROS TORRES ${ }^{2}$, \\ CLARISSE PEREIRA BENEDITO ${ }^{2}$, MARIA LILIA DE SOUZA NETA², EMANOELA PEREIRA DE PAIVA ${ }^{2 *}$
}

\begin{abstract}
This study aimed to establish an adequate tetrazolium test procedure to estimate okra seed viability. Initially, seeds from four okra lots were immersed in alcohol (98\%) for 60 minutes, followed by an 18 -h soak in distilled water at $25{ }^{\circ} \mathrm{C}$. Then, the seeds were longitudinally sectioned, immersed in $0.025,0.050$ and $0.075 \%$ tetrazolium solutions for 60,90 and 120 minutes and maintained in an oven at 35 and $40{ }^{\circ} \mathrm{C}$. Subsequently, the seeds were evaluated for viability, based on tissue color (bright red, pink or dark Carmine red). Simultaneously, a germination test was conducted, and its results were used as a reference for the tetrazolium test. The experiment was carried out in a completely randomized design, in a $3 \times 3+1$ factorial scheme (three concentrations of tetrazolium salt $\mathrm{x}$ three immersion periods, plus the control) in four replicates of 50 seeds for each treatment. The tetrazolium test to estimate okra seed viability should be conducted in $0.075 \%$ tetrazolium solution, for 90 minutes, at $35^{\circ} \mathrm{C}$.
\end{abstract}

Keywords: Malvaceae. Biochemical test. Quick tests.

\section{TESTE DE TETRAZÓLIO PARA ESTIMAR A VIABILIDADE EM SEMENTES DE QUIABO (Abelmoschus esculentus (L.) MOENCH)}

RESUMO - Objetivou-se estabelecer o procedimento adequado do teste de tetrazólio para estimar a viabilidade em sementes de quiabo. Inicialmente, as sementes de quatro lotes de quiabo foram imersas em álcool (98\%) por 60 minutos e seguida de 18 horas de embebição em água destilada a $25{ }^{\circ} \mathrm{C}$. Após este período, as sementes foram seccionadas longitudinalmente, imersas em soluções de tetrazólio de 0,$025 ; 0,050$ e $0,075 \%$ por 60,90 e 120 minutos e mantidas em estufa a 35 e $40{ }^{\circ} \mathrm{C}$. Posteriormente, as sementes foram avaliadas quanto à viabilidade, tendo como indicação a coloração dos tecidos (vermelho brilhante rosa ou vermelho carmim forte). Paralelamente, foi instalado o teste de germinação, cujos resultados serviram como referência para o teste de tetrazólio. O experimento foi conduzido em delineamento inteiramente casualisado, em esquema fatorial $3 \times 3$ +1 , (três concentrações do sal de tetrazólio x três períodos de imersão e a testemunha) em quatro repetições de 50 sementes para cada tratamento. $\mathrm{O}$ teste de tetrazólio para estimar a viabilidade em sementes de quiabo deve ser realizado em solução de tetrazólio de $0,075 \%$, por 90 minutos, a $35^{\circ} \mathrm{C}$.

Palavras-chave: Malvaceae. Teste bioquímico. Testes rápidos.

\footnotetext{
${ }^{*}$ Corresponding author

${ }^{1}$ Received for publication in $07 / 05 / 2017$; accepted in 10/17/2017.

Paper extracted from the master thesis of the first author.

${ }^{2}$ Center of Agricultural Sciences, Universidade Federal Rural do Semi-Árido, Mossoró, RN, Brazil; adailhatorres@hotmail.com - ORCID: 0000-0003-3934-8912, narjara.nogueira@ufersa.edu.br - ORCID: 0000-0002-6242-463X, sbtorres@ufersa.edu.br ORCID: 0000-0003-0668-3327, clarisse@ufersa.edu.br - ORCID: 0000-0002-2846-1162, lilia.agronomia@hotmail.com ORCID: 0000-0002-2108-7526, emanuelappaiva@hotmail.com - ORCID: 0000-0003-4510-9205.
} 


\section{INTRODUCTION}

Okra [Abelmoschus esculentus (L.) Moench] is an annual vegetable, native to Africa and introduced in Brazil by slaves (FILGUEIRA, 2008). Due to its rusticity and being considered a crop of low production cost, this species has been grown in regions of tropical and subtropical climate and does not require advanced technology for its cultivation (LOPES et al., 2010). It is widely cultivated in Brazil and is very important for the economy and society, but there remains a lack of research into okra, particularly concerning its seeds (TORRES et al., 2014).

Using seeds with a high physiological potential is a requisite for obtaining a uniform plant stand in the field and, therefore, for maximizing production. Thus, the standard method to assess seed physiological quality is the germination test. However, for okra seeds, this test has limitations, especially regarding the relatively long time of 21 days required to inform results and make decisions (BRASIL, 2009).

In this context, the tetrazolium test has been widely used in quality control programs to evaluate seed viability in a fast and effective way, especially for species with dormancy or slow germination, such as okra seeds (MARCOS FILHO, 2015; BRASIL, 2009).

Nevertheless, various factors interfere with conducting a tetrazolium test, such as solution concentration, temperature, seed exposure time and seed preparation before staining (PAIVA et al., 2017).

The tetrazolium test has been used to assess the physiological quality of various species, such as soybean (FRANÇA-NETO; KRYZANOWSKI; COSTA, 1998), Brachiaria (NOVEMBRE; CHAMMA; GOMES, 2006), maize (CHAMMA; NOVEMBRE, 2007), cotton (CERVI; MENDONÇA, 2009), sunflower (SILVA et al., 2013) and wheat (CARVALHO et al., 2013), because of its quality and fast results. Among vegetables, this test has been used to assess the viability of seeds of zucchini (BARROS et al., 2005), tomato (SANTOS; NOVEMBRE; MARCOS FILHO, 2007), watermelon (NERY; CARVALHO; OLIVEIRA, 2007) and cucumber (LIMA; PINTO; NOVEMBRE, 2010). However, for okra seeds, there is no information available on the use of tetrazolium test in internal programs of quality control, probably due to the scarce research on the standardization of the methodology for this species.

Given the above, this study aimed to establish an adequate tetrazolium test procedure to estimate okra seed viability.

\section{MATERIAL AND METHODS}

The research was carried out at the Seed Analysis Laboratory of the Center of Agrarian Sciences of the Federal Rural University of the Semi-Arid Region (UFERSA), Mossoró-RN, Brazil, using four lots of okra seeds, cultivar Santa Cruz 47, provided by national seed-producing companies in the 2013/2014 season. The lots were initially characterized and subjected to the following evaluations: 1) moisture content - a method using an oven at $105^{\circ} \mathrm{C}$, for 24 hours, with two subsamples of $5 \mathrm{~g}$ of seeds per lot. The results were calculated based on wet weight, according to the Rules for Seed Analysis (RAS) (BRASIL, 2009). 2) A germination test - conducted for comparison with the tetrazolium test results. Four replicates of 50 seeds were used for each lot and the seeds were sown at a $3-\mathrm{cm}$ depth on trays containing washed and sterilized sand as substrate, moistened with distilled water at a proportion of $60 \%$ field capacity. The temperature during the test was alternated between 20 and $30{ }^{\circ} \mathrm{C}$ and seeds were counted 21 days after sowing, with results expressed as a percentage of normal seedlings (BRASIL, 2009). 3) Tetrazolium test - a preliminary test was conducted to establish the best pre-conditioning procedure and seed preparation necessary to obtain adequate color to evaluate and interpret the tests. Seeds were pre-moistened through direct immersion in alcohol $(98 \%)$ for 60 minutes, followed by washing in running water, soaked again in $50 \mathrm{~mL}$ of distilled water and maintained in a Biochemical Oxygen Demand (B.O.D.) chamber for 18 hours at $25{ }^{\circ} \mathrm{C}$ (EICHELBERGER; MORAES, 2001). Subsequently, seeds were placed in tetrazolium solutions at concentrations of $0.025 \%$, $0.05 \%$ and $0.075 \%$, for periods of 60,90 and 120 minutes, at temperatures of $35^{\circ} \mathrm{C}$ and $40{ }^{\circ} \mathrm{C}$, in the absence of light.

The tetrazolium test was conducted using four replicates of 50 seeds from all lots separately, for each combination between solution concentration and staining period, totaling nine treatments. After each staining period, the solution was drained, and the seeds were washed in running water and were maintained submerged in water, arranged in a refrigerator until evaluation. The seeds were individually evaluated using a benchtop stereo magnifier microscope (6x) for the presence or absence of color, location and intensity.

Differences in seed tissue colors were verified according to the criteria established for the tetrazolium test by França-Neto, Kryzanowski and Costa (1998). According to these authors, viable seeds have embryos with completely light pink or bright red color and radicle tip without milky/yellowish white color. Seeds whose embryos exhibited a completely Carmine red/intense red or milky/yellowish white color, and whose radicle tip was uncolored or intense red, were classified as unviable. The results were expressed as a percentage of viable seeds. 
The experiment was carried out in a completely randomized design (CRD), in a $3 \times 3+1$ factorial scheme (three concentrations of tetrazolium salt and three staining periods, plus the control germination test) at temperatures of $35^{\circ} \mathrm{C}$ and $40{ }^{\circ} \mathrm{C}$ for each lot. Data were subjected to analysis of variance by the $\mathrm{F}$ test. Means of viable seeds from the tetrazolium test were compared using a Tukey test with a 0.05 probability level being considered as significant. Means of tetrazolium and germination tests were compared using a Dunnett's test at a 0.5 probability level. Statistical analyses were performed using the program ASSISTAT 7.7 beta (SILVA; AZEVEDO, 2002).

\section{RESULTS AND DISCUSSION}

Initially, seeds from the different okra lots showed an average moisture content of $11.3 \%$ (Table 1). A similar moisture content between lots is essential so that tests are not affected by differences in metabolic activities, moistening speed and seed deterioration intensity (MARCOS FILHO, 2015).

Table 1. Initial water content of okra seed lots [Abelmoschus esculentus (L.) Moench], cultivar Santa Cruz 47.

\begin{tabular}{cc}
\hline Lots & Water content (\%) \\
\hline 1 & 10.9 \\
2 & 12.0 \\
3 & 11.2 \\
4 & 11.2 \\
\hline Means & 11.3 \\
\hline
\end{tabular}

In the tetrazolium test, the concentration of $0.075 \%$, regardless of seed exposure time to the solution at $35{ }^{\circ} \mathrm{C}$, led to a higher percentage of viable seeds for lot 1 (Table 2). The results of viable seeds obtained for this same concentration for the 90-minute period are consistent with those of the germination test. The $0.025 \%$ concentration for the 60-minute period resulted in a lower viability percentage compared with the other concentrations and exposure periods.

Table 2. Feasibility of okra seeds [Abelmoschus esculentus (L.) Moench] from the tetrazolium test conducted at different concentrations and staining periods under the temperature of $35^{\circ} \mathrm{C}$.

\begin{tabular}{|c|c|c|c|}
\hline & \multicolumn{3}{|c|}{ Concentrations of tetrazolium (\%) } \\
\hline Periods (minutes) & $0.025^{*}$ & 0.050 & 0.075 \\
\hline \multicolumn{4}{|c|}{ Lot 1} \\
\hline 60 & $43 \mathrm{bCy}$ & 65 aBy & 73 aAy \\
\hline 90 & 68 aBy & 68 aBy & $79 \mathrm{aAx}$ \\
\hline 120 & 74 aAy & 69 aAy & $76 \mathrm{aAy}$ \\
\hline \multicolumn{3}{|c|}{ Germination (\%) } & $88 \mathrm{x}$ \\
\hline \multicolumn{4}{|c|}{ Lot 2} \\
\hline 60 & 35 bBy & 74 aAy & $82 \mathrm{aAx}$ \\
\hline 90 & 75 aABy & 70 aBy & $82 \mathrm{aAx}$ \\
\hline 120 & 74 aAy & 69 aAy & $19 \mathrm{bBy}$ \\
\hline \multicolumn{3}{|c|}{ Germination (\%) } & $90 x$ \\
\hline \multicolumn{4}{|c|}{ Lot 3} \\
\hline 60 & 40 aAy & $51 \mathrm{aAx}$ & $45 \mathrm{bAx}$ \\
\hline 90 & $41 \mathrm{aBy}$ & $45 \mathrm{aAx}$ & $49 \mathrm{bAx}$ \\
\hline 120 & $40 \mathrm{aBy}$ & $41 \mathrm{aBy}$ & $61 \mathrm{aAx}$ \\
\hline \multicolumn{3}{|c|}{ Germination (\%) } & $57 x$ \\
\hline \multicolumn{4}{|c|}{ Lot 4} \\
\hline 60 & $34 \mathrm{cCy}$ & 43 bBy & 74 bAy \\
\hline 90 & $60 \mathrm{bCy}$ & 74 aBy & $86 \mathrm{aAx}$ \\
\hline 120 & 79 aAy & $72 \mathrm{aBy}$ & $85 \mathrm{aAx}$ \\
\hline \multicolumn{3}{|c|}{ Germination (\%) } & $91 \times$ \\
\hline
\end{tabular}

*Means followed by the same capital letter $(\mathrm{A}, \mathrm{B}, \mathrm{C})$ and lower in the line $(\mathrm{a}, \mathrm{b}, \mathrm{c})$ in column are not significantly different by Tukey test at $5 \%$ probability. Means followed by the same letter (x,y), between germination (control $=$ germination test) and viability obtained in the tetrazolium test did not differ significantly from each other by the Dunnett test at $5 \%$ probability.

The concentrations of $0.025 \%$ for 60 minutes and $0.075 \%$ for 120 minutes caused a low percentage of viable seeds in lot 2 , of 35 and $19 \%$, respectively, due to a weak and intense red color in most seeds, which were considered unviable (Table 2). In addition, the $0.075 \%$ concentration for the periods of 60 and 90 minutes resulted in estimates similar to those of the control $(90 \%)$ for the germination test results. These results agree with those observed by Lima, Pinto and Novembre (2010) in cucumber 
seeds for the efficiency of tetrazolium salt concentration of $0.075 \%$ for 60 minutes.

The results obtained in lot 3 were similar to those of lot 1 , for which the percentage of viable seeds increased with the increment in solution concentration and seed staining period, but without differences between the concentrations 0.050 and $0.075 \%$ for the period of 90 minutes, and 0.025 and $0.05 \%$ for the period of 120 minutes (Table 2). Also in lot 3, viability estimates obtained in concentrations $0.05 \%$ and $0.075 \%$ for the periods of 60 and 90 minutes, as well as for $0.075 \%$ for the period of 120 minutes, did not differ from the control $(57 \%)$ in the germination test, suggesting that these procedures are suitable for evaluating okra seeds viability. Hence, coherence was observed between the results of tetrazolium and germination tests for lots 1,2 and 4 with higher viability and lot 3 with lower viability (Table 2 ).

It should be highlighted that, among the tested lots, seeds from lot 3 showed lower viability and lower germination. This lot also exhibited a greater amount of deteriorating seeds, which may have contributed to its low physiological quality.

Lot 4 showed a low estimate of seed viability when subjected to the $0.025 \%$ concentration, for the periods of 60 and 90 minutes, and compared with the 120 -minute period for the same concentration. This may be attributed to the weak color intensity of the seeds under such a condition.

At the highest tetrazolium concentration $(0.075 \%)$, seed viability estimates increased for the periods of 90 and 120 minutes, corroborating the results obtained in the germination test of lot 4 (Table 2).

In general, okra seed exposure to the $0.075 \%$ tetrazolium solution concentration for 90 minutes at $35{ }^{\circ} \mathrm{C}$ led to the best results in the viability evaluation (Table 2), since the results of tetrazolium and germination tests were consistent for all lots in this treatment. Similar results were obtained by Bhering, Dias and Barros (2005) and Nery, Carvalho and Oliveira (2007), in watermelon seeds, in which the $0.075 \%$ tetrazolium solution concentration was adequate and allowed a more consistent evaluation, due to the more uniform color patterns. On the other hand, for sunflower seeds, when a low concentration solution was used in association with a short period of exposure to the solution, seed viability was low (SILVA et al., 2013), as for the results obtained in lots 2 and 4 in the present study.

For the viability percentage of seeds from lot 1 at the temperature of $40{ }^{\circ} \mathrm{C}$, the combination between concentrations and staining periods led to a variation of shades for the exposure periods of 60 and 90 minutes. When associated with the $0.025 \%$ concentration, these periods were considered as insufficient to estimate okra seed viability, probably due to the poor staining of the tissues and, in some cases, to the lack of color, resulting in a low percentage of viable seeds. On the other hand, these periods when associated with the concentrations of 0.050 and $0.075 \%$ promoted increments in the estimates of seed viability (Table 3 ).

Table 3. Feasibility of okra seeds [Abelmoschus esculentus (L.) Moench], cultivar Santa Cruz 47, from the tetrazolium test conducted at different concentrations and staining periods under the temperature of $40^{\circ} \mathrm{C}$.

\begin{tabular}{|c|c|c|c|}
\hline & \multicolumn{3}{|c|}{ Concentrations of tetrazolium (\%) } \\
\hline Periods (minutes) & 0.025 & 0.050 & 0.075 \\
\hline \multicolumn{4}{|c|}{ Lot 1} \\
\hline 60 & $20 \mathrm{cBy}$ & 75 bAy & 73 aAy \\
\hline 90 & 27 bBy & 77 bAy & 77 aAy \\
\hline 120 & $84 \mathrm{aAx}$ & $82 \mathrm{aAx}$ & $63 \mathrm{bBy}$ \\
\hline \multirow{2}{*}{\multicolumn{4}{|c|}{ Germination (\%) }} \\
\hline & & & \\
\hline 60 & 68 bAy & 67 bAy & $67 \mathrm{bAy}$ \\
\hline 90 & $82 \mathrm{aAx}$ & 74 bAy & 77 aAy \\
\hline 120 & $82 \mathrm{aAx}$ & $82 \mathrm{aAx}$ & $10 \mathrm{cBy}$ \\
\hline \multirow{2}{*}{\multicolumn{4}{|c|}{ Germination (\%) }} \\
\hline & & & \\
\hline 60 & $47 \mathrm{aAx}$ & $56 \mathrm{aAx}$ & 15 bBy \\
\hline 90 & $46 \mathrm{aAx}$ & 35 bAy & 38 aAy \\
\hline 120 & $23 \mathrm{bAy}$ & $11 \mathrm{cBy}$ & 5 bBy \\
\hline \multirow{2}{*}{\multicolumn{4}{|c|}{ Germination $(\%)$}} \\
\hline & & & \\
\hline 60 & $69 \mathrm{bCy}$ & 77 abAy & 75 bAy \\
\hline 90 & $57 \mathrm{cBy}$ & 71 bAy & 75 bAy \\
\hline 120 & $83 \mathrm{aBx}$ & $83 \mathrm{aBx}$ & $91 \mathrm{aAx}$ \\
\hline \multicolumn{4}{|c|}{ Germination $(\%)$} \\
\hline
\end{tabular}

*Means followed by the same capital letter $(\mathrm{A}, \mathrm{B}, \mathrm{C})$ and lower in the line $(\mathrm{a}, \mathrm{b}, \mathrm{c})$ in column are not significantly different by Tukey test at $5 \%$ probability. Means followed by the same letter $(x, y)$, between germination (control = germination test) and viability obtained in the tetrazolium test did not differ significantly from each other by the Dunnett test at $5 \%$ probability. 
Still regarding lot 1 , higher viability percentages were observed in the 120 -minute period at concentrations of 0.025 and $0.050 \%$. Hence, these combinations promoted a clear color of the embryos (Figure 1), facilitating the analysis and interpretation of the results, without differing from the germination test in relation to the control $(88 \%)$. Regarding the effect of concentrations for each staining period, the increment in tetrazolium concentration resulted in an increased estimate of viability for the periods of 60 and 90 minutes, whereas for the longest period (120 minutes), the highest concentration $(0.075 \%)$ led to a reduction in seed viability (Table 3 ).
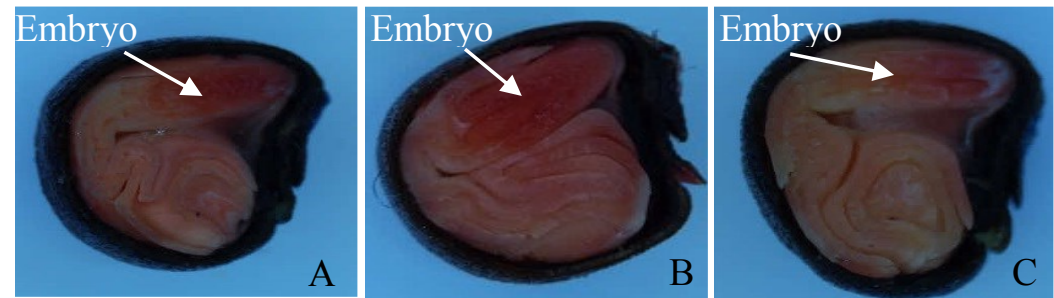

Figure 1. Viable seeds of okra [Abelmoschus esculentus (L.) Moench], cultivar Santa Cruz 47: (A) seeds with uniform light pink color, tissues with normal and firm appearance without lesions of the embryo; (B) bright pink embryo, with small areas or spots with more intense staining; (C) or with small points deteriorated, but without reaching the vital region.

For lot 2 , the $0.025 \%$ concentration promoted viability evaluation for the periods of 90 and 120 minutes, whereas for $0.050 \%$, the evaluation was only possible in a longer period of exposure (120 $\mathrm{min}$ ), and the results of these combinations were similar to those obtained in the germination test
$(90 \%)$. On the other hand, the $0.075 \%$ concentration did not allow evaluation in any of the periods, especially 120 minutes (Table 3), which resulted in a substantial reduction of seed viability $(10 \%)$, probably due to excessive coloring (Figure 2).

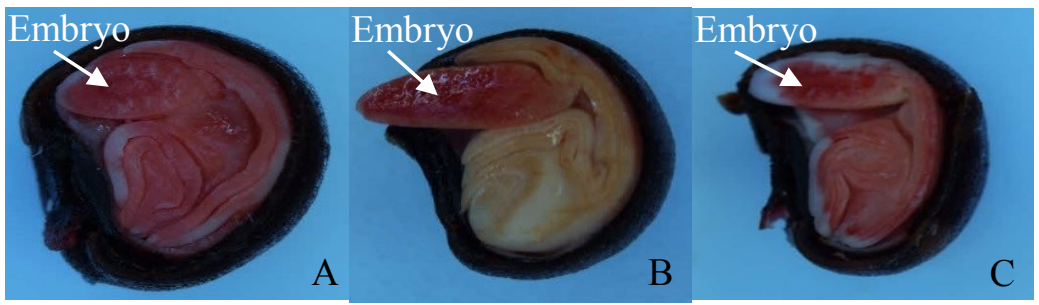

Figure 2. Non-viable okra seeds [Abelmoschus esculentus (L.) Moench], cultivar Santa Cruz 47: (A) seeds with more than $50 \%$ of cotyledons with intense red color; (B) discolored or necrotic showing an embryonic axes with intense red color; (C) cotyledons with intense red coloration and discolored regions reaching the central cylinder.

Lot 3 , for being the least vigorous among the evaluated lots, showed a high number of seeds with intense red color (indication of advanced degree of deterioration); thus, it was only possible to evaluate the viability according to germination in shorter staining periods (60 and 90 minutes). The combination of 120 minutes, for all concentrations, was inadequate for evaluating the viability of okra seeds, which exhibited large patches of intense red color in the embryos, indicating an excessive exposure period and a strong concentration of tetrazolium solution (Figure 2).

Another aspect observed during the analysis of lot 3 was the presence of cracks in some seeds, which probably facilitated the internal diffusion of the tetrazolium solution. This result corroborates the information of Costa and Santos (2010), who highlighted the importance of adequate absorption of the solution by the seeds because, when viable, they tend to absorb the solution slowly, developing a lighter color than deteriorated seeds, which exhibit a strong pink color.
For seeds from lot 4 , the viability results were higher as the staining period and tetrazolium solution concentration increased. Hence, the highest values of viability were obtained for the 120-minute period, associated with the $0.075 \%$ concentration (Table 3 ). As observed in the present study, Cervi and Mendonça (2009), in cotton seeds, found that the $0.075 \%$ tetrazolium salt concentration, at $40{ }^{\circ} \mathrm{C}$ and the 150-minute exposure period were adequate for a uniform color of the seeds.

For the temperatures studied to adjust the tetrazolium test to okra seeds, it was observed that, in seeds maintained at the temperature of $35{ }^{\circ} \mathrm{C}$, viability was successfully evaluated at the highest concentration $(0.075 \%)$, in the 90 -minute period (Table 2). However, for seeds stored at the temperature of $40{ }^{\circ} \mathrm{C}$, none of the treatments accurately represented the results expressed in the germination test, so that lots with high and low viability cannot be characterized by the same treatment (Table 3). Therefore, the temperature of $35{ }^{\circ} \mathrm{C}$ proved to be more efficient to evaluate okra

Rev. Caatinga, Mossoró, v. 31, n. 4, p. 817 - 822, out. - dez., 2018 
seeds in a shorter time, with higher consistency.

\section{CONCLUSION}

The tetrazolium test to estimate viability of okra seeds should be conducted in a $0.075 \%$ tetrazolium solution, for 90 minutes, at $35^{\circ} \mathrm{C}$.

\section{REFERENCES}

BARROS, D. I. et al. Uso do teste de tetrazólio para avaliação da qualidade fisiológica de sementes de abobrinha. Revista Brasileira de Sementes, Londrina, v. 27, n. 2, p. 165-171. 2005.

BHERING, M. C.; DIAS, D. C. F. S.; BARROS, D. I. Adequação da metodologia do teste de tetrazólio para avaliação da qualidade fisiológica de sementes de melancia. Revista Brasileira de Sementes, Londrina, v. 27, n. 1, p. 176-182, 2005.

BRASIL. Ministério da Agricultura, Pecuária e Abastecimento. Secretaria de Defesa Agropecuária. Coordenação Geral de Apoio Laboratorial. Regras para análise de sementes. Brasília, DF: MAPA/ ACS, 2009. 395 p.

CARVALHO, T. C. et al. Tetrazolium test adjustment for wheat seeds. Journal of Seed Science, Londrina, v. 35, n. 3, p. 361-367, 2013.

CERVI, F.; MENDONÇA, E. A. F. Adequação do teste de tetrazólio para sementes de algodoeiro. Revista Brasileira de Sementes, Londrina, v. 31, n. 1, p. 177-186, 2009.

CHAMMA, H. M. C. P.; NOVEMBRE, A. D. L. C. Teste de tetrazólio para as sementes de milho: períodos de hidratação e de coloração das sementes. Revista Brasileira de Sementes, Londrina, v. 29, n. 2, p. 125-129, 2007.

COSTA, C. J.; SANTOS, C. P. Teste de tetrazólio em sementes de leucena. Revista Brasileira de Sementes, Londrina, v. 32, n. 2, p. 66-72, 2010.

EICHELBERGER, L.; MORAES, D. M. Preparo de sementes de quiabo [Abelmoschus esculentus (L.) Moench] para o teste de tetrazólio. Revista Brasileira de Sementes, Londrina, v. 23, n. 1, p. 154 $-158,2001$.

FILGUEIRA, F. A. R. Novo manual de olericultura: Agrotecnologia moderna na produção e comercialização de hortaliças. 3. ed. Viçosa, MG: Ed UFV, 2008. p. 421.
FRANÇA-NETO, J. B.; KRYZANOWSKI, F. C.; COSTA, N. P. O teste de tetrazólio em sementes de soja. Londrina: EMBRAPA/ CNPSo, 1998. 72 p. (EMBRAPA-CNPSo. Documentos, 116).

LIMA, L. B.; PINTO, T. L. F.; NOVEMBRE, A. D. L. C. Avaliação da viabilidade e do vigor de sementes de pepino pelo teste de tetrazólio. Revista Brasileira de Sementes, Londrina, v. 32, n. 1, p. 6068, 2010.

LOPES, M. M. et al. Teste de envelhecimento acelerado em sementes de quiabo. Bioscience Journal, Uberlândia, v. 26, n. 4, p. 491-501, 2010.

MARCOS FILHO, J. Fisiologia de sementes de plantas cultivadas. 2. ed. Londrina, PR: ABRATES, 2015. $660 \mathrm{p}$

NERY, M. C.; CARVALHO, M. L. M.; OLIVEIRA, L. M. Teste de tetrazólio para avaliação da qualidade fisiológica de sementes de melancia. Semina: Ciências Agrárias, Londrina, v. 28, n. 3, p. 365-372, 2007.

NOVEMBRE, A. D. L. C.; CHAMMA, H. M. C. P.; GOMES, R. B. R. Viabilidade das sementes de braquiária pelo teste de tetrazólio. Revista Brasileira de Sementes, Londrina, v. 28, n. 2, p. 147 $-151,2006$.

PAIVA, E. P. et al. Teste de tetrazólio para avaliação da viabilidade de sementes de maxixe. Revista Ciência Agronômica, Fortaleza, v. 48, n. 1, p. 118124, 2017.

SANTOS, M. A. O.; NOVEMBRE, A. D. L. C.; MARCOS FILHO, J. Tetrazolium test to assess viability and vigour of tomato seeds. Seed Science and Technology, Zurich, v. 35, n. 1, p. 213-223, 2007.

SILVA, F. A. S. E.; AZEVEDO, C. A. V. Versão do programa computacional Assistat para o sistema operacional Windows. Revista Brasileira de Produtos Agroindustriais, Campina Grande, v. 4, n. 1, p. 71-78, 2002.

SILVA, R. C. et al. Adaptação do teste de tetrazólio para avaliação da viabilidade e do vigor de sementes de girassol. Pesquisa Agropecuária Brasileira, Brasília, v. 48, n. 1, p. 105-113, 2013.

TORRES, S. T. et al. Diferenciação de lotes de sementes de quiabo pelo teste de envelhecimento acelerado. Ciência Rural, Santa Maria, v. 44, n. 12, p. 2103-2110, 2014. 